\title{
Mathematical Representation of the Grade 11 of Senior High School Students in Solving Linear Programming Questions Based on David Keirsey's Personality Type
}

\author{
Didik Sugeng Pambudi ${ }^{1, *}$ Randi Pratama Murtikusuma ${ }^{2}$ Dinawati Trapsilasiwi $^{3}$ \\ Ervin Oktavianingtyas ${ }^{4}$ Inge Wiliandani ${ }^{5}$ Tiara Prita Ningrum ${ }^{6}$ \\ 1,2,3,4,5,6 Department of Mathematics Education, Faculty of Teacher Training and Education, University of Jember, \\ *Corresponding author. Email: didikpambudi.fkip@unej.ac.id
} Indonesia

\begin{abstract}
The aim of this study is to define the student mathematical representation of Grade 11 high school in solving linear programming questions based on David Keirsey's personality type. This research were analyzed through a qualitative description. The research was conducted at Senior High School 1 Jember. Data is obtained based on questionnaires, linear programming research questions and interviews. Subjects based on the similarity of the linear programming test results of each type of personality. Each personality has two subjects of study. The results revealed that Artisan students used mathematical and visual expression representation forms. The Idealist students used mathematical, visual, and verbal representation forms. The Guardian students used only the representation form for mathematical expression. Whereas Rational students used only the representation form of mathematical and verbal expression.
\end{abstract}

Keywords: Mathematical representation, David Keirsey's Personality Type, Linear Programming.

\section{INTRODUCTION}

Mathematics is a compulsory subject from elementary to secondary level Informal education. This is because mathematics is really important in actual life. Certain disciplines also underlie the application of mathematics. Not just counting but sharpening thinking skills is the purpose of mathematics. The ability to think is a means of addressing a specific problem. The ability to think consider the ability of problem solving, reasoning and proof, connections, communication, and representation [1].

Representation is a way by students express their interpretation of previously taught concepts [2]. Representation is an expression of students mathematical ideas or ideas for solving a problem [3]-[5]. Representation is used to translate a more meaningful symbolic thing to make it easier to comprehend [6]-[7]. Representation is often used to channel ideas which are then communicated to the environment.
We can divide representations into two internal and external representations [6], [8]-[10]. It closely relates internal and external representations to each other. If students cannot understand internal representations, then external representations will not be displayed properly. Internal representation is an idea that still exists in the mind and has not been expressed. It closely relates internal representation to students' thinking abilities. While external representation is an idea that has been expressed in written or oral form. External representation can divide into three representation namely verbal representation, figure representation, and symbolic presentation [11]. Whereas according to Bruner, representation comprises enactive, iconic, and symbolic [12].

The purpose of learning mathematics communicates ideas with symbols, tables, diagrams, or other media to clarify the situation or problem [13]. This relates to representation. In mathematics, each student needs the form of mathematical representation. But in reality, 
students are still hesitant in conveying ideas to solve a mathematical problem. This is because of lack of understanding of theories and concepts [14]. A problem can be expressed in one or more ways of representation to improve the analysis of a problem [15]. Therefore, each student must be able to master all forms of representation. One material in mathematics that has over one representation is a linear programming.

Each student can have differences in solving a problem related to mathematics. The difference is because each student has criteria to solve mathematical problems easily. The personality of students can influence one of these differences. Personality is divided into two, among others the most prominent skills and impressions [16]. Meanwhile personality is associated with perception, attitude, learning, and motivation [17]. Each person has distinct personalities and this can influence behavior in the environment [18]. Differences in personality can also affect learning that impacts the environment

Various personality types in this world, one of them is personality type according to David Keirsey. In his book entitled Please Understand Me II states that personalities are based on four types including: artisan, idealist, guardian, and rational [19]. In a learning, guardian type follows the class with routine procedures and regular instructions. Artisan types like class with a lot of discussion. The idealist type enjoys solving tasks in groups. Whereas the rational type likes to study independently.

\section{METHODS}

This research is a qualitative descriptive. Study tools, including questionnaire questions of personality type, linear programming tests questions and interview guidelines, are the steps in performing this research. Three validatory tested the research instrument. In this analysis, the selection of subjects is based on the similarity of the mathematical representation in each type of personality. There were two subjects in each personality selected in this review. In addition, mathematical representation in addressing linear programming problems has been better understood through interviews. The triangulation method accomplished by aligning the results of the analysis and the interview analysis of the linear programming test questions.

Table 1. Indicators of Mathematical Representation

\begin{tabular}{|l|l|}
\hline Representation & \multicolumn{1}{c|}{ Indicator } \\
\hline $\begin{array}{l}\text { Mathematical } \\
\text { expression }\end{array}$ & $\begin{array}{l}\text { a. Making mathematical expression } \\
\text { from a problem }\end{array}$ \\
\hline
\end{tabular}

\begin{tabular}{|l|l|}
\hline Representation & \multicolumn{1}{c|}{ Indicator } \\
\hline & $\begin{array}{l}\text { b. Solving problem by involving } \\
\text { mathematical expression }\end{array}$ \\
\hline $\begin{array}{l}\text { Visual (picture, } \\
\text { graphic, } \\
\text { diagram, or } \\
\text { table) }\end{array}$ & $\begin{array}{l}\text { Representing data to visual } \\
\text { representation to clarify problem }\end{array}$ \\
\hline Verbal (words) & $\begin{array}{l}\text { Solving problem by using verbal or } \\
\text { words representation }\end{array}$ \\
\hline
\end{tabular}

\section{RESULT AND DISCUSSION}

This research conducted at Senior High School 1 Jember of the grade 11 MIPA 7 with 30 students comprising 4 students with artisan personality, 5 students with idealist personality, 12 students with guardian personality, and 9 students with rational personality. The selected research subjects in each personality type were 2 students. Artisan personality students selected with SA1 and SA2, idealist personality students selected with SI1 and SI2, guardian personality students selected with SG1 and SG2, and rational personality students selected with SR1 and SR2.

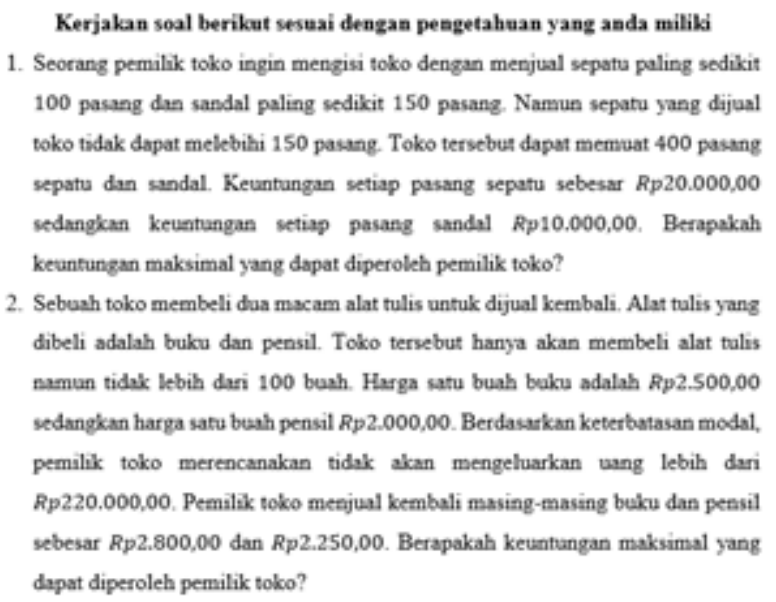

Figure 1 Linear programming test

\subsection{Artisan Personality Type}

Figure 2 show artisan subject results. Based on result, mathematical representation of students with artisan personality in solving linear programming test questions using the form of mathematical and visual expression representations. This is appropriate with previous research which shows that mathematical literacy profiles of artisan subject apply solutions using symbol representations, which are a form of mathematical representation [20]. In solving the linear programming problems, artisan subject writes an example and make a mathematical model. Then the subject determines the intersection point to draw the graph using the help of tables and calculations. Before determining the profit function, the artisan subject first determines the area of 
completion on the graph so they can determine the intersection point, which is then substituted on the objective function that has been created. The artisan subject can determine the maximum profit he mentioned as the maximum value. But artisan subject does not write the conclusion of the answers on the student answer sheet. This is appropriate with previous research which shows that students with artisan personality types do not write conclusions and do not re-check answers [21].

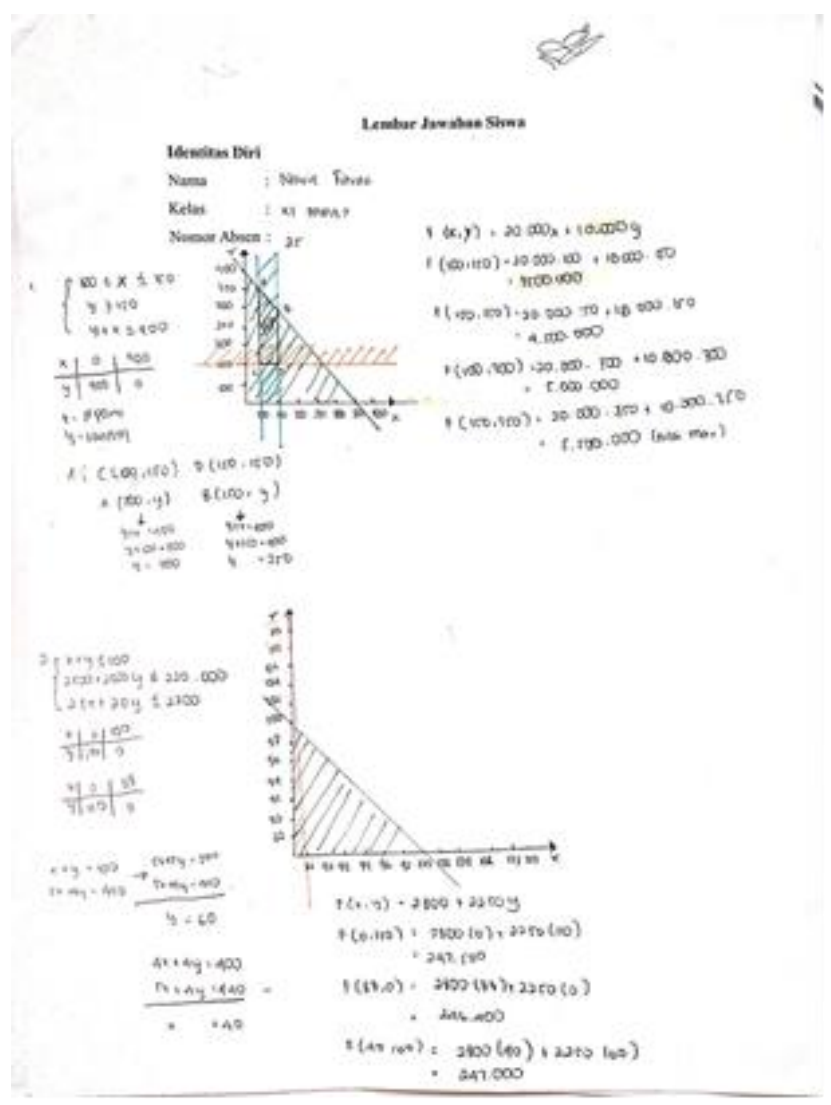

Figure 2 Subject answer (SA1)

\subsection{Idealist Personality Type}

Figure 3 show idealist subject results. Mathematical representation of idealist personality in the resolving of linear programming test questions using the mathematical representation of expressions, visual and verbal representations. This is appropriate with previous research which shows that the idealist student literacy profile recognizes significant variables by converting into maths, symbols and images [20]. The idealist subject writes an example and generates a mathematical model for the solution of linear programming problems. The idealist subject decides the crossroads to draw the charts using formulas of exclusion and substitution. Before deciding the function of profit, the idealist subject first defines the area of completion of the graph so they can decide the point of intersection which is then replaced by the objective function which has been performed. Then Idealist subject write sentence results on the student answer sheet.

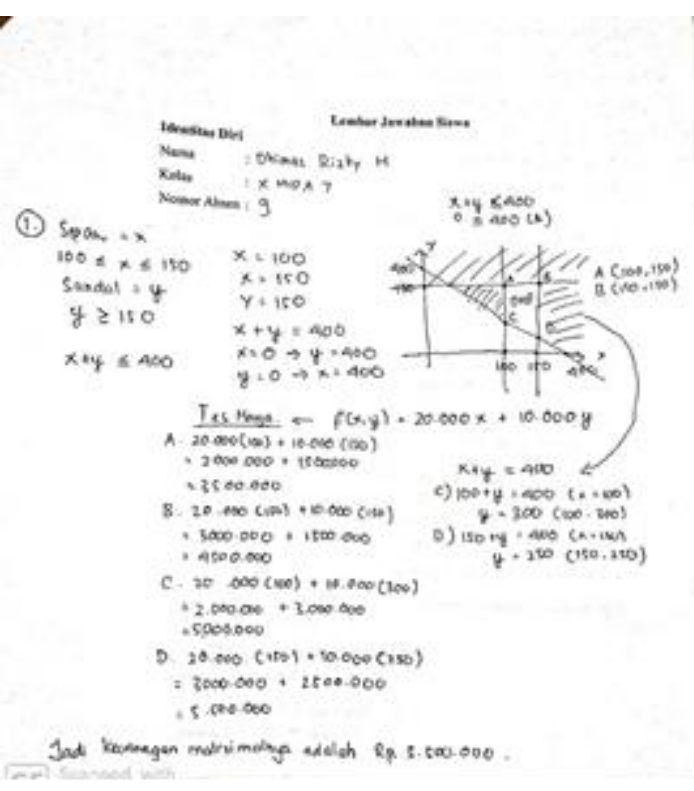

Figure 3 Subject answer (SI1)

\subsection{Guardian Personality Type}

Figure 4 show guardian subject result. Mathematical representation of guardian personality in solving linear programming test questions only uses the form of mathematical expression representation. In solving the linear programming problem, guardian subject writes an example and make a mathematical model. Guardian subject determine the cut points using elimination and substitution calculations. Guardian subject make objective functions and determine the maximum profit value. But guardian subject does not write their conclusions in sentence form on the student answer sheet

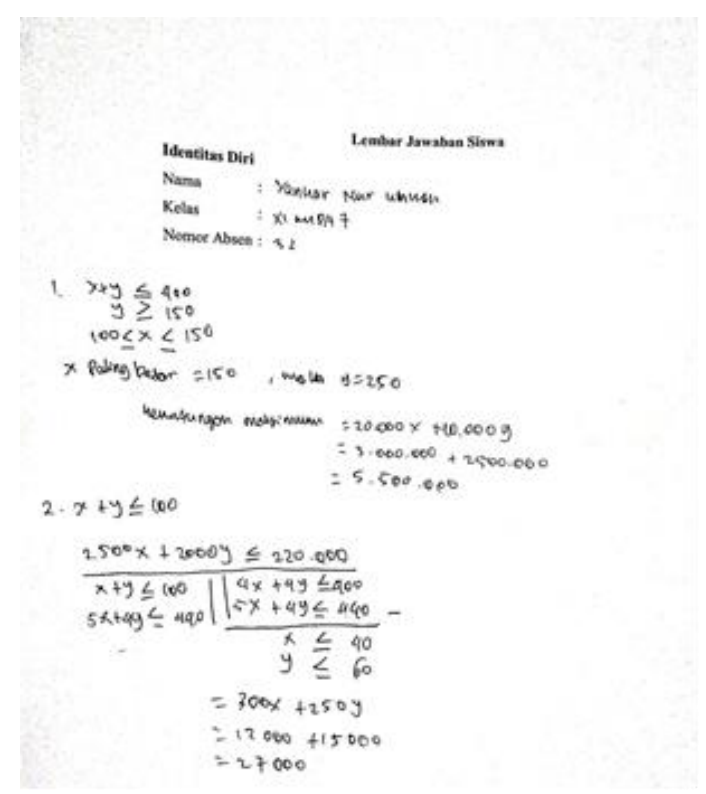

Figure 4 Subject answer (SG1) 


\subsection{Rational Personality Type}

Figure 5 show rational subject results. Mathematical representation of students with rational personality in solving linear programming test questions only uses the form of mathematical representation of expressions and verbal representations. This is appropriate with previous research which shows that profiles of rational subject mathematical literacy use mathematical language, symbols and images to solve problems. [20]. However, in this study rational subject do not use visual representation. In solving the linear programming problem, students rationally write an example and make a mathematical model. The rational subject determines the cut points by using elimination and substitution calculations. The rational subject decides objective functions and determine the maximum profit value. However, the rational subject does not write conclusions in sentence form on student answer sheets.

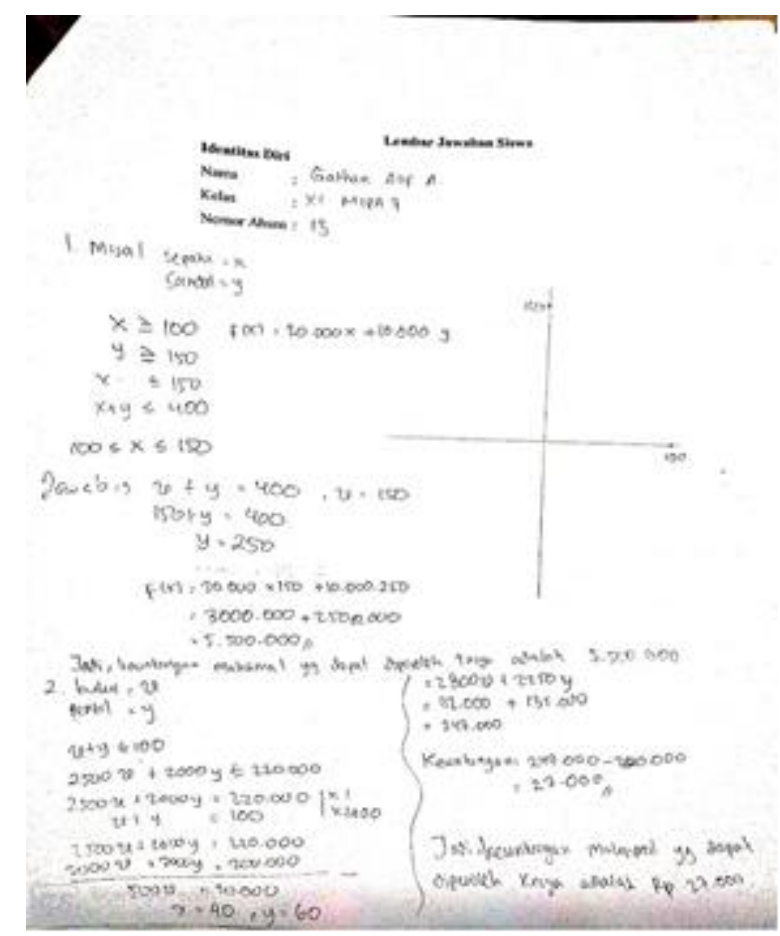

Figure 5 Subject answer (SR1)

\section{CONCLUSION}

The result for data analysis shows that students with artisan personalities can present the mathematical expressions of a problem, solve mathematical problems, and present the data to illustrate a problem as visual representations. Students of idealist personality can mathematically depict problems, solve mathematical expressions problems, present data as visual representations to clarify the problem and resolve issues through verbal representations as words. Students with personality types of guardian will mathematically reflect problems and solve mathematical problems. Although rational personality types can interpret a problem in a mathematical form, problems with mathematical expressions can be resolved and solve problems with verbal representations as words.

\section{AUTHORS' CONTRIBUTIONS}

All authors participated in collecting data and analyzing data in this study.

\section{ACKNOWLEDGMENTS}

The author expressing gratitude to the lecturers of Mathematics Education Department of Jember University, Senior High School 1 Jember, and Manabel research group who helped gather data and inspired the author.

\section{REFERENCES}

[1] NCTM, Principles and Standards for School Mathematics (United States of America: The National Council of Teachers of Mathematics, Inc), 2000 .

[2] S. K. Selling, The Journal of Mathematical Behavior Learning to Represent, Representing to Learn Journal Math. Behavior vol 41 pp 191-209, 2016.

[3] Kartini, Peranan Representasi dalam Pembelajaran Matematika Prosiding Seminar Nasional Matematika dan Pendidik. Mat. UNY pp 361-372, 2009.

[4] N. Rahmadian, Mulyono, and Isnarto, Kemampuan Representasi Matematis dalam Model Pembelajaran Somatic , Auditory , Visualization , Intellectually ( SAVI ) Prosiding Seminar Nasional Matematika vol 2 pp 287-292, 2019.

[5] M. Sabirin, Representasi dalam Pembelajaran Matematika Jurnal Pendidikan Matematika vol $1 \mathrm{p}$ 33-44, 2017.

[6] A. F. Samsudiin and H. Retnawati, Mathematical Representation: The Roles, Challenges and Implication Journal of Physics Conference Series vol 1097 pp 1-7, 2018.

[7] R. Mitchell, C. Y. Charalambous, and H. C. Hill, Examining The Task And Knowledge Demands Needed To Teach With Representations Math Teach. Education vol 17 pp 37-60, 2014.

[8] L. D. English et al., Handbook Of International Research In Mathematics Education Perspectives On Representation And Problem Solving no 10872, 2017. 
[9] H. A. Susanto, Pemahaman Pemecahan Masalah Berdasar Gaya Kognitif (Yogyakarta: Deepublish), 2015.

[10] S. J. Pape and M. Tchoshanov, The Role of Representation ( $\mathrm{s}$ ) in Developing Mathematical Understanding vol 40 pp 118-127, 2015.

[11] J. L. Villegas, E. Castro, and J. Gutiérrez, Representations in Problem Solving: a Case Study with Optimization Problems Electron Journal Res. Educ. Psychol.vol 7 pp 279-308, 2009.

[12] M. A. Hebert and S. R. Powell, Examining FourthGrade Mathematics Writing: Features And Mathematical Representations Read. Writ, 2016.

[13] Permendiknas, Peraturan Menteri Pendidikan Nasional Republik Indonesia Nomor 23 tahun 2006 tentang Standar Kompetensi Lulusan untuk Satuan Pendidikan Dasar dan Menengah, 2006.

[14] S. Saifiyah and H. Retnawati, Why is Mathematical Representation Difficult for Students? Why is Mathematical Representation Difficult for Students? Journal of Physics Conference Series vol 1397 p 1-9, 2019.

[15] R. Kang and D. Liu, The Importance of Multiple Representations of Mathematical Problems: Evidence from Chinese Preservice Elementary Teachers' Analysis of a Learning Goal Int. Journak Science Mathematics Education, 2016.

[16] Sunaryo, Psikologi untuk Keperawatan (Jakarta: Buku Kedokteran EGC), 2002.

[17] J. M. Ivancevich, R. Konopaske, and M. T. Matteson, Perilaku dan Manajemen Organisasi (Jakarta: Erlangga), 2006.

[18] W. Winarso, Pengaruh Perbedaan Tipe Kepribadian Terhadap Sikap Belajar Matematika Siswa Sma Islam Al-Azhar 5 Cirebon Jurnal Pendidikan Matematika vol 2 pp 94, 2017.

[19] D. Keirsey, Please Understand Me II: Temperament, Character, Intelligence. (America: Prometheus Nemesis), 1998.

[20] Masriyah and M. H. Firmansyah, Students' Mathematical Literacy in Solving PISA Problems Based on Keirsey Personality Theory Journal of Physics Conference Series vol 953 pp 1-7, 2018.

[21] R. W. Y. Putra et al, The Analysis of the Mathematical Problem-Solving Ability of High School Students Reviewed from Personality Types of the Rational and Artisan Journal Physics Conference Series vol 1155 pp 1-7, 2019.

[22] E. Komala and D. Suryadi, Analysis of Internal and External Mathematical Representation Ability to
Senior High School Students in Indonesia Journal of Physics Conference Series vol. 1132 pp 1-10 